\title{
Rhizoclonium ramosum sp. nov. (Cladophorales, Chlorophyta), a new fresh- water algal species from China
}

\author{
Zhi-Juan ZHAO ${ }^{1,2}$, Huan Zhu ${ }^{1}$, Guo-Xiang LiU ${ }^{1 *} \&$ Zheng-Yu Hu${ }^{3}$ \\ ${ }^{1}$ Key Laboratory of Algal Biology, Institute of Hydrobiology, Chinese Academy of Sciences, Wuhan 430072, P. \\ R. China; *Corresponding authore-mail:liugx@ihb.ac.cn \\ ${ }^{2}$ University of Chinese Academy of Science, Beijing 100049, P. R. China \\ ${ }^{3}$ State key Laboratory of Freshwater Ecology and Biotechnology, Institute of Hydrobiology, Chinese Academy \\ of Sciences, Wuhan 430072, P. R. China
}

\begin{abstract}
A novel freshwater filamentous green alga was collected from rocks situated in flowing water in Henan and Hunan provinces, central China. This alga was slender and soft and exhibited similar morphology to that of Rhizoclonium spp. It was attached to the substrate by rhizoids, and had parietal, reticulate chloroplasts. However, it exhibited true branches characteristic, from the basal to the apical parts of the filaments. There were a large number of nuclei (4-17) per cell. Two types of pyrenoids (bilenticular and, rarely, zonate) were observed using light microscopy and transmission electron microscopy. Phylogenetic analyses were mainly based on small subunit and large subunit rDNA sequences. Both morphological and phylogenetic analyses indicated that this alga should be classified under Rhizoclonium. The results of our culture and morphological comparisons supported the presence of true branches in Rhizoclonium. Thus, we proposed this alga as a new species, Rhizoclonium ramosum sp. nov. Moreover, the present study emphasizes that the cell diameter, length/ cell diameter (L/D) ratio, nuclear number, and the presence of rhizoidal laterals are the key characteristics of the genus Rhizoclonium.
\end{abstract}

Key words: Rhizoclonium, true branches, phylogeny, new species, Cladophorales

\begin{abstract}
Abbreviations: (L/D ratio) cell length/cell diameter ratio, (SSU rDNA) small subunit rDNA, (LSU rDNA) large subunit rDNA, (LM) light microscopy, (TEM) transmission electron microscopy, (HBI) Freshwater Algal Herbarium, (L:D cycle) light:dark cycle, (FAA) formaldehyde-acetic acid-alcohol, (PCR) polymerase chain reaction, (ML) maximum likehood, (BI) Bayesian inference, (hLRT) hierarchical likelihood ratio tests, (MCMC) Markov chain Monte Carlo
\end{abstract}

\section{INTRODUCTION}

The genus Rhizoclonium (Cladophorales, Chlorophyta) was established by KüTZING (1843) who segregated it from the genus Conferva. Rhizoclonium species are found in environments with varying salinities, ranging from marine to fresh waters, but they are mainly found in brackish waters (KütZing 1849; Setchell \& GARDNER 1920; JoHn et al. 2002). There are 71 species names in the database, but only 27 are currently taxonomically accepted (GUIRY \& GUIRY 2015).

Rhizoclonium species were described by some taxonomists, such as: Kützing (1843), Blair (1983), Posada \& Crandall (1998) etc. About 7 Rhizoclonium species have been reported in freshwater environments so far, including $R$. riparium, $R$. hieroglyphicum, $R$. pachydermum, $R$. fractiflexum, $R$. crassipellitum, $R$. fontanum, $R$. fontinale. $R$. riparium and $R$. hieroglyphicum grow attached to other substrates by rhizoids. These two species are common and have a broad geographical distribution. (LiU 1999). GARDAVSKY (1993) reported $R$. fractiflexum characterized by frequent and marked bending of filaments in the place of insertion of rhizoidal laterals. $R$. pachydermum is the first freshwater Rhizoclonium species recorded having real branches (KJeLLMANN 1877; ZhaO et al. 2014).

Following the traditional definition, the genus Rhizoclonium is characterized mainly by uniseriate, unbranched filaments (CHAPMAN 1956; BlaiR 1983). The filaments are usually attached to soft or hard substrata or to other algae by rhizoids or holdfasts (NIENhUIS 1975; Blair 1983). Some Rhizoclonium species produce sparse rhizoidal laterals, containing one to a few cells (Starmach 1972; LiU 1999). The number of 
nuclei, in contrast to Cladophora species (ICHIHARA et al. 2013; ZHAO et al. 2014), is limited (usually 1-4, sometimes up to 8) (Verma 1986). Pyrenoid morphology was used as a criterion for characterizing families, genera, and especially species in green algae (MiYAJI 1999). Recent literature has used pyrenoid morphology as a taxonomic characteristic in Cladophorales (VAN Den Hoek \& ChiHara 2000; Hanyuda et al. 2002). Until now, three pyrenoid morphologies have been recognized in the genus Rhizoclonium: bilenticular, zonate (a variant of the bilenticular pyrenoid with two intrapyrenoidal thylakoids), and polypyramidal (MIYAJ 1999).

The aim of the present study was to describe a new Rhizoclonium species collected from China. We observed the morphology and assessed its phylogenetic position based on nuclear-encoded small subunit (SSU) and large subunit (LSU) rDNA sequences. The pyrenoid ultrastructure, used as a diagnostic character for the lineage, was observed using light microscopy (LM) and transmission electron microscopy (TEM). We discussed the morphological circumscriptions of Rhizoclonium by comparing our new species with related species.

\section{Materials and Methods}

Sample collection and morphological observation. Specimens HEN1407 and HUN1439 were sampled from Mt. Yuntai $\left(35^{\circ} 25^{\prime} \mathrm{N}, 113^{\circ} 25^{\prime} \mathrm{E}\right)$, Henan Province from rocks situated in flowing waters in April 2013, and Zhangjiajie National Forest Park $\left(29^{\circ} 18^{\prime} \mathrm{N}, 110^{\circ} 26^{\prime} \mathrm{E}\right)$, Hunan Province from rocks in a waterfall in November 2014, respectively. Natural samples were isolated using an Olympus SZX7 stereoscope and rinsed with double-distilled $\mathrm{H}_{2} \mathrm{O}$. Environmental samples were preserved in $10 \%$ formaldehyde and deposited in the Freshwater Algal Herbarium (HBI), Institute of Hydrobiology,
Chinese Academy of Science, under the accession numbers HEN1407 and HUN1439, respectively.

Natural samples were cut and rinsed several times in phosphate-buffered saline ( $\mathrm{pH}=7.0$ ). The algae were cultured on sterilized BG11 medium solidified with $1.2 \%$ agar, at $20{ }^{\circ} \mathrm{C}$ with a $14: 10-\mathrm{h}$ light:dark (L:D) cycle under fluorescent light at $30 \mu \mathrm{mol} . \mathrm{m}^{-2} . \mathrm{s}^{-1}$.

We observed the morphology of the filaments under differential interference contrast and epifluorescence microscopy using a Leica DM5000B microscope. The morphology included cell diameter, length/diameter (L/D) ratio, chloroplast morphology, branches, and rhizoids. The micrographs were captured using a Leica DFC320 digital camera. Pyrenoids and the nuclei were fixed with FAA solution (90 $\mathrm{ml} 50 \%$ ethanol $+5 \mathrm{ml}$ acetic acid $+5 \mathrm{ml} 38 \%$ formaldehyde) and then the nuclei were stained with $0.01 \%$ SYBR Green. The pyrenoid ultrastructure of samples was examined by LM and TEM and showed a number of thylakoids entering the pyrenoid, as well as the arrangement of the starch plates. The TEM method was largely based on the methods described by NitschKe et al. (2010). The nuclei were observed using microscopy (DM5000B; Leica, Wetzlar, Germany).

DNA extraction, amplification and phylogenetic analyses. Filaments were isolated under the Olympus SZX7 stereoscope and washed in $\mathrm{ddH}_{2} \mathrm{O} 3-4$ times. Single cells from filaments were cut using scalpels, and inclusions of 10-20 cells were added to $50 \mu \mathrm{TE}$ buffer, and $20 \mathrm{mg} . \mathrm{l}^{-1}$ proteinase $\mathrm{K}$ was added to this solution. The mixtures were incubated at $56^{\circ} \mathrm{C}$ for $30 \mathrm{~min}$, then at $95^{\circ} \mathrm{C}$ for $5 \mathrm{~min}$, and finally stored at $-20^{\circ} \mathrm{C}$.

Molecular phylogenetic analyses were based on nuclear-encoded small subunit (SSU) and partial large subunit (LSU) rDNA sequences, respectively. A combination of the primers SR1-SS11H and SSU897-18SC2 was used to amplify SSU sequences (LeLIAERT \& BoEdeKer 2007). The polymerase chain reaction (PCR) started with 3 min at $94{ }^{\circ} \mathrm{C}$, followed by 35 cycles of $1 \mathrm{~min}$ at $94^{\circ} \mathrm{C}, 1 \mathrm{~min}$ at $55^{\circ} \mathrm{C}$, and $1 \mathrm{~min} 30 \mathrm{~s}$ at $72^{\circ} \mathrm{C}$, ending with a final extension at $72^{\circ} \mathrm{C}$ for $3 \mathrm{~min}$. The LSU PCR amplifications started with $5 \mathrm{~min}$ at 94 ${ }^{\circ} \mathrm{C}$, followed by 31 cycles of $30 \mathrm{~s}$ at $94{ }^{\circ} \mathrm{C}, 30 \mathrm{~s}$ at $57^{\circ} \mathrm{C}$, and
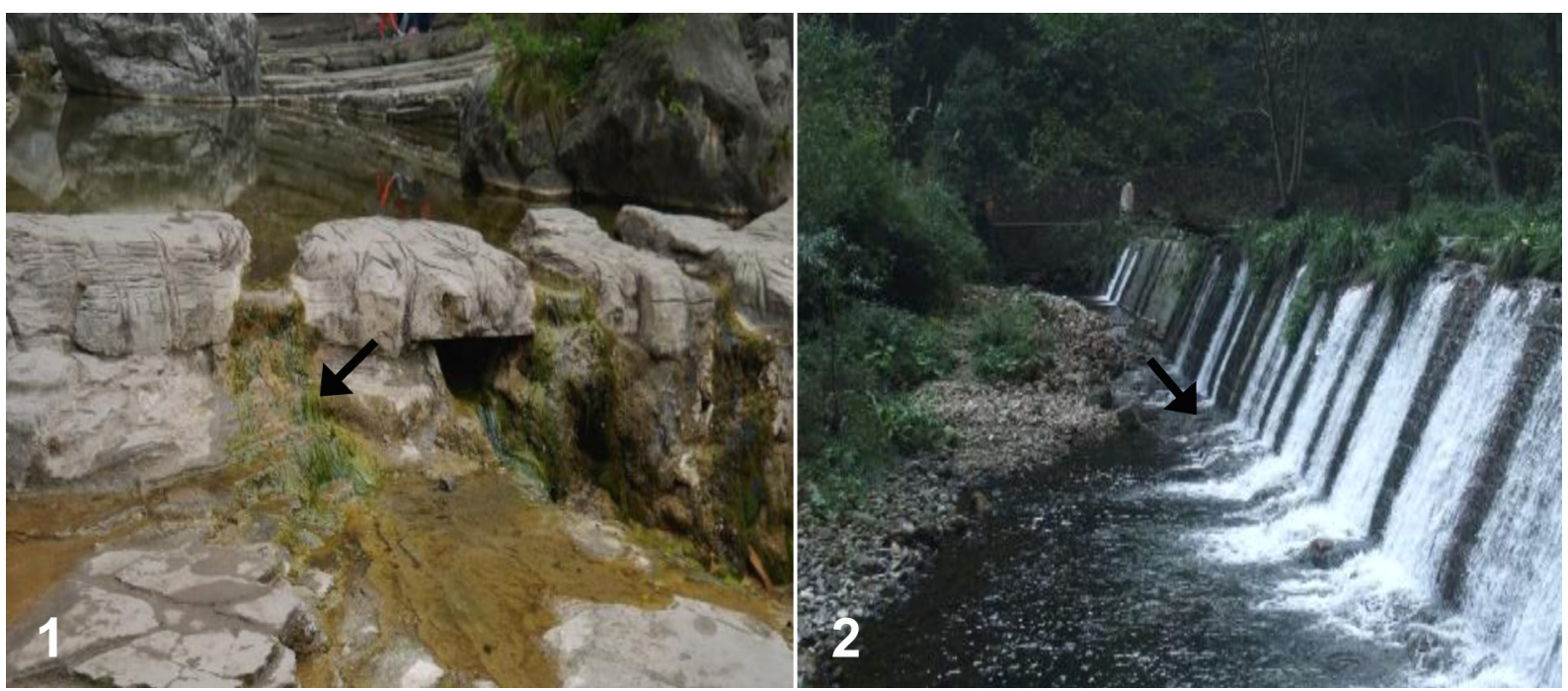

Figs 1-2. Collection sites of Rhizoclonium ramosum sp. nov.: (1) Natural habitat of the sample HEN1407 collected from Mt. Yuntai, Henan Province, attached on the rocks under flowing water; (2) Natural habitat of the sample HUN1439 collected from Zhangjiajie National Forest Park, Hunan Province, growing on the surface of rocks under a waterfall. 
$30 \mathrm{~s}$ at $72{ }^{\circ} \mathrm{C}$, ending with a final hold of 5 min at $72{ }^{\circ} \mathrm{C}$. The LSU rDNA were amplified using the universal primers $\mathrm{C}^{\prime} 1$ forward (5'-ACCCGCTGAATTTAAGCATAT- $\left.3^{\prime}\right)$ and D2 reverse (5'-TCCGTGTTTCAAGACGG-3') (HAssounA et al. 1984; LELIAERT et al. 2003). PCR products were visualized by staining with ethidium bromide after electrophoresis on a $1.5 \%$ agarose gel. All PCR amplicons were cleaned with an AxyPrep DNA Gel Extraction Kit (Axygen Biotechnology, Hangzhou, China) following the manufacturer's instructions. These products were sent to Tsingke Biotech Co. Ltd, China, for sequencing.

Reference sequences for phylogenetic analyses were downloaded from GenBank (http://www.ncbi.nlm.nih.gov/). Only some common and core members of Pithophoraceae, and Siphonocladus, Cladophora, and Rhizoclonium clades were chosen and included in the SSU and LSU alignments, as well as the outgroup (Ulothrix zonata and Ulva fascia$t a)$. The sequences were initially aligned using Clustal X (v. 1.83) (THOMPson \& WuJEK 1997) and refined manually with BioEdit version 5.0.9 (HALL 1999). To improve alignment, highly variable regions that could not be aligned unambiguously were excluded, resulting in 1602 positions for the SSU rDNA dataset and 537 positions for the LSU rDNA dataset.

The SSU and LSU rDNA alignments were analysed using maximum likelihood (ML). The same models of nucleotide evolution were applied to both ML analyses in PAUP 4.0* (v. 4.0 beta) (Swofford 1998) and Bayesian inference (BI) in MrBayes. Model parameters for ML analyses were determined from hierarchical likelihood ratio tests (hLRT) (HuELSENBeck \& Crandall 1997) using Mo- deltest (v. 3.06) (Posada \& Crandall 1998). Bootstrapping was carried out with 100 replicates using a heuristic search strategy. The best-fit evolutionary model for both SSU and LSU rDNA datasets was GTR + I + G. BI was used with MrBayes v3.1.2 (Ronquist \& HuelsenbeCK 2003). Posterior probabilities were calculated using a Markov chain Monte Carlo (MCMC) analyses, run with seven Markov chains (six heated, one cold) for $5 \times 10^{6}$ generations, with sampling every 1000 generations. Topologies were summarized using the sumt command, with the first quarter discarded as burn-in. An average standard deviation lower than 0.01 of the split frequencies between two parallel runs indicated that a stationary distribution was reached. A burn-in sample of 1250 trees was removed before calculating the majority-rule consensus trees in MrBayes.

\section{Results}

Rhizoclonium ramosum Z. Zhaо et G. LiU sp. nov. (Figs 1-22)

\section{Description}

LM observations: Freshwater alga, green, slender, and soft, attached to the surfaces of rocks (Figs 1,2). Thalli clustered, about 1-2.5 cm long (Fig. 3). True branches present from the basal region to the apical parts, laterally inserted, and often deflected from the

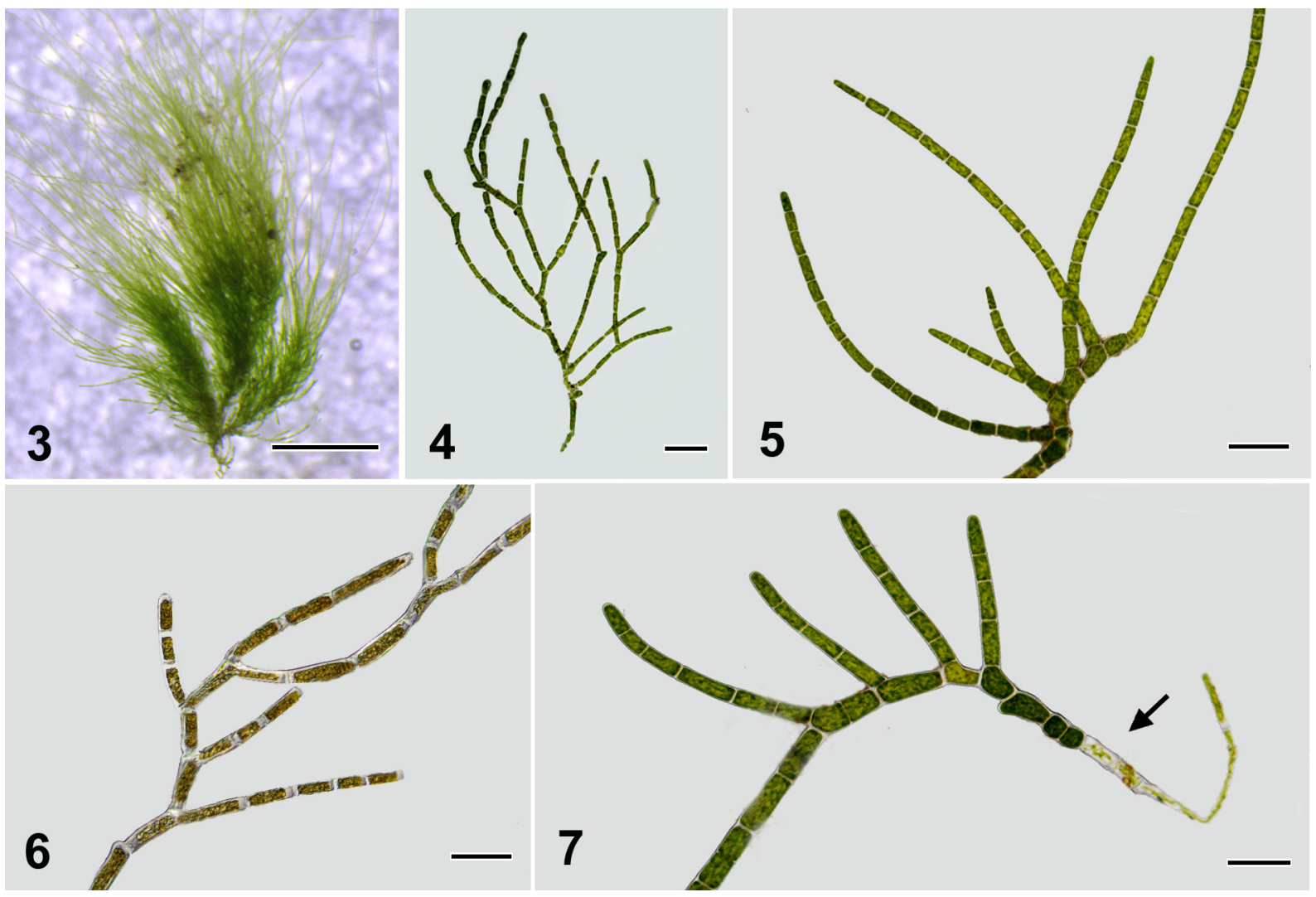

Figs 3-7. The miscroscopy of Rhizoclonium ramosum from the field: (3) Clustered thalli. Note the long, and branched filaments; $(4,5,6)$ Showing the branches of a single filament with primary and secondary branches; (7) Basal region. Showing the branches and rhizoids with chloroplasts lacking (arrow). Scale bar $5 \mathrm{~mm}(3), 200 \mu \mathrm{m}(4), 100 \mu \mathrm{m}(5,6,7)$. 


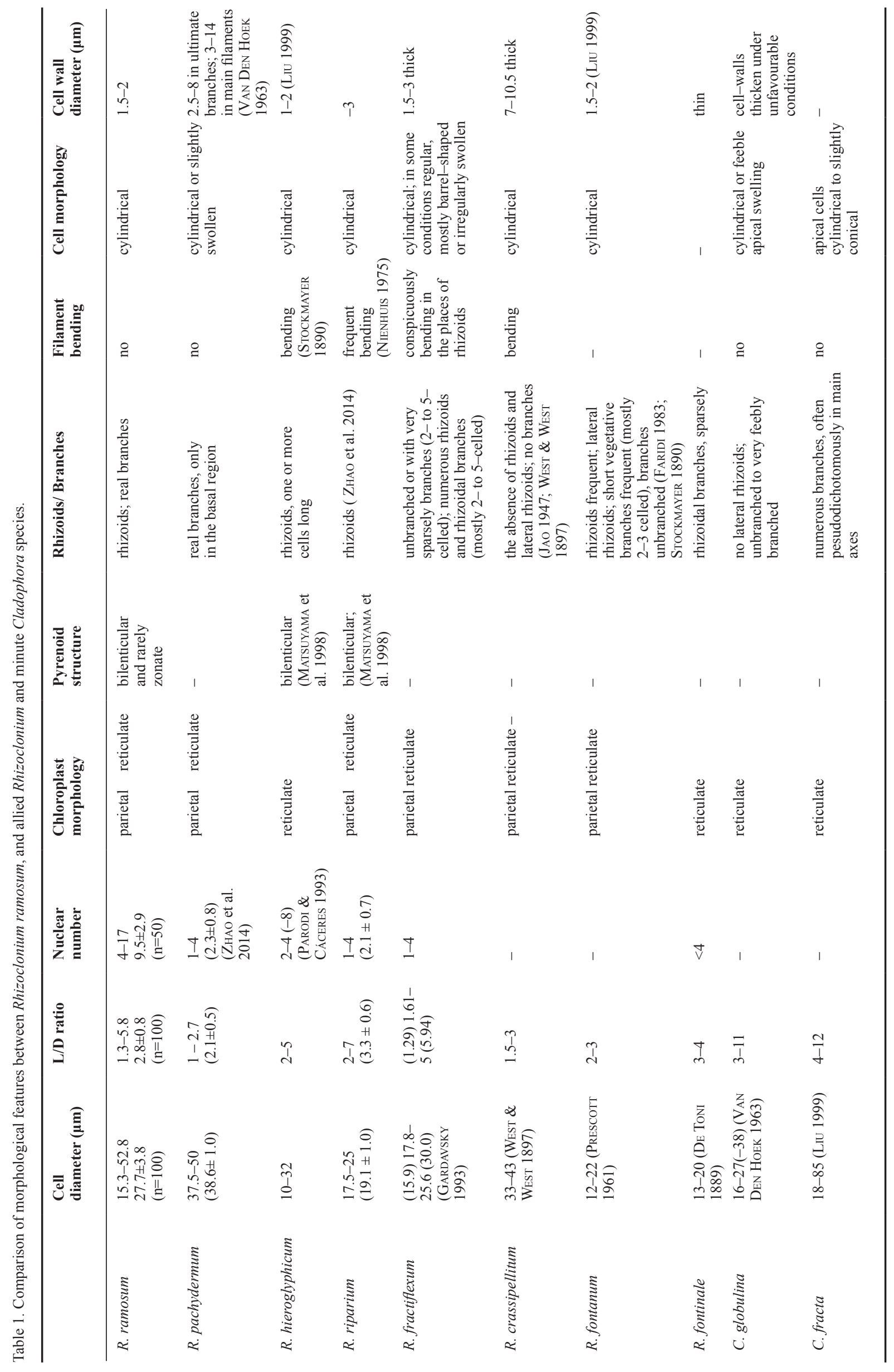




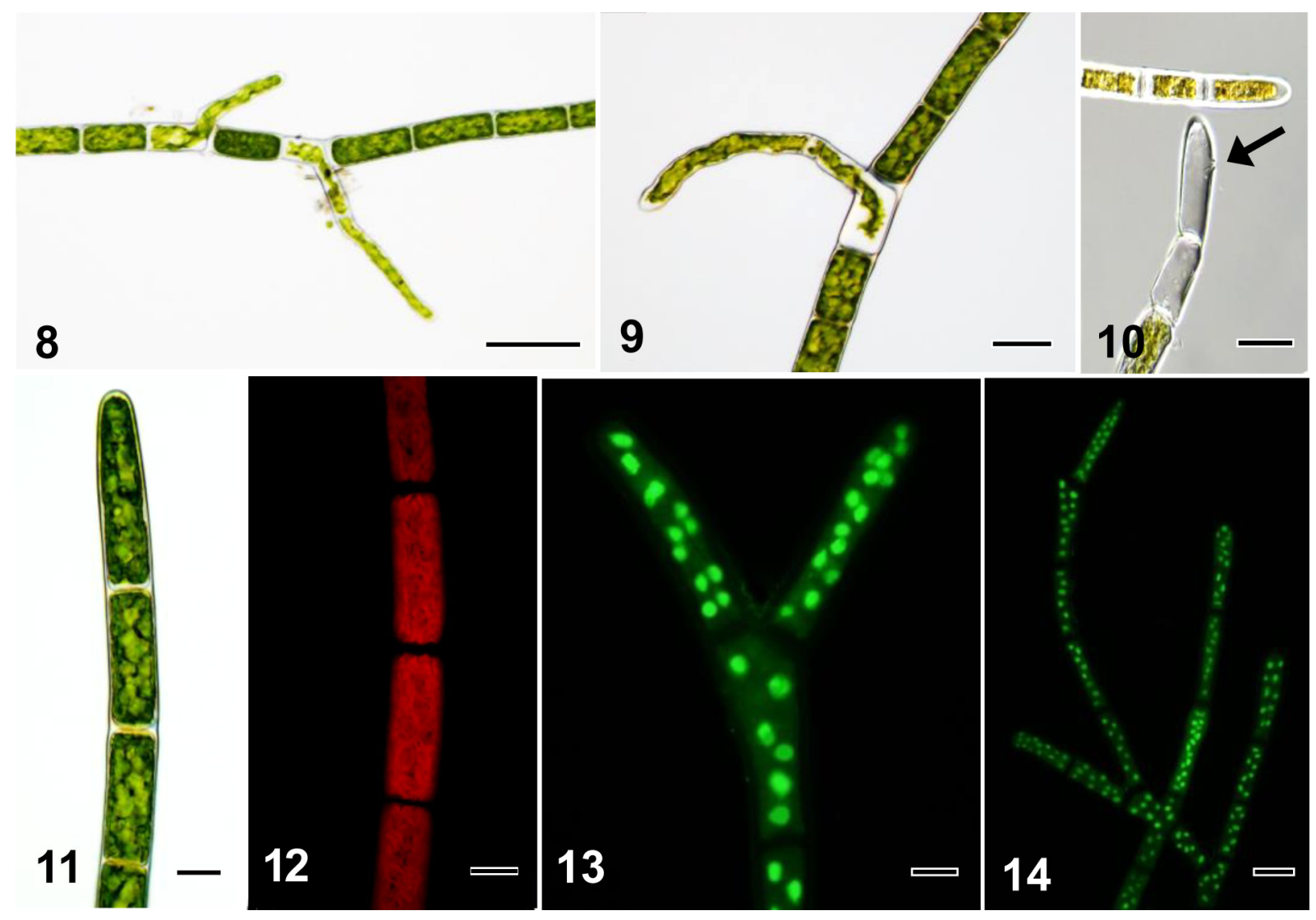

Figs 8-14. The cell morphology of Rhizoclonium ramosum: $(8,9)$ Showing the morphology of rhizoidal laterals with few cells and chloroplasts lacking or uneven; $(10)$ The arrow indicating a lateral pore where the gametes liberated; $(11,12)$ Structure of apical cells and reticulate chloroplasts by the autofluorescence; $(13,14)$ Autofluorescence showing the number of nuclei. Scale bar $100 \mu \mathrm{m}(8), 50 \mu \mathrm{m}(9,10,14), 20 \mu \mathrm{m}$ $(11,12,13)$.

axis (Figs 4-6). Thallus attached using simple basal rhizoids, with chloroplasts sometimes absent or uneven and often one cell long, or longer (Fig. 7). Rhizoidal laterals sparse and irregular, usually containing one to a few cells (Figs 8, 9). Long unbranched filaments growing by intercalary cell divisions. A lateral pore, in the upper middle part of cells, along the sporangia where the zoospores were liberated (Fig. 10). Cells cylindrical, 15.3-52.8 $\mu \mathrm{m}$ in diameter, with a length/ diameter (L/D) ratio of 1.3-5.8 (Table 1). Chloroplasts, parietal and arranged in a reticulate pattern (Figs 11, 12). Nuclear number up to $4-17$ per cell (Figs 13, 14).

After two weeks in culture, new branches observed on thalli grown on solid medium (Figs 15-18), and filaments developed primary and secondary branches (Figs 17, 18). Under culture conditions, branches were slow-growing and composed of 1-4 cells. New cells cylindrical with parietal reticulate chloroplasts, 25-40 $\mu \mathrm{m}$ in diameter (as wide as the main axes), and an $\mathrm{L} / \mathrm{D}$ ratio of $2-4$. In culture, no rhizoids and rhizoidal branches developed.

TEM observations: Pyrenoids were usually distributed in both the internal and peripheral places of the chloroplast, and were either spherical or ellipsoidal (Fig. 19). There were 5-30 pyrenoids per cell, varying with the cell size, and were $2.3-5.0 \mu \mathrm{m}$ in diameter (n
$=60$ ). There were two pyrenoid types. The majority of pyrenoids in $R$. ramosum cells were bilenticular with the surrounding starch layer divided into two halves by a single intrapyrenoidal thylakoid (Figs 20, 21). Other, rare pyrenoids were zonate in structure, characterized by a double thylakoid penetrating the pyrenoid matrix and producing three starch plates (Fig. 22).

Holotype: Deposited as HEN1407 in the Freshwater Algal Herbarium (HBI), Institute of Hydrobiology, Chinese Academy of Science, Wuhan, Hubei Province, China.

Iconotype: Fig. 4.

Type locality: HEN1407 (HBI) Mt. Yuntai $\left(35^{\circ} 25^{\prime} \mathrm{N}\right.$, $113^{\circ} 25^{\prime} \mathrm{E}$ ), Henan Province, China; attached to the rocks under flowing water, collected on 10 April 2014 by Zhi-Juan Zhao.

Distribution and habitat: The plant has been found only in Mt. Yuntai, Henan Province and Zhangjiajie National Forest Park, Hunan Province so far. It grows on the rocks under waterfalls.

Etymology: The epithet of the new species refers to the morphological structures of the thalli, which have true branches from the basal to the apical parts.

\section{Phylogenetic analyses}

The sequence information used in this study is listed 


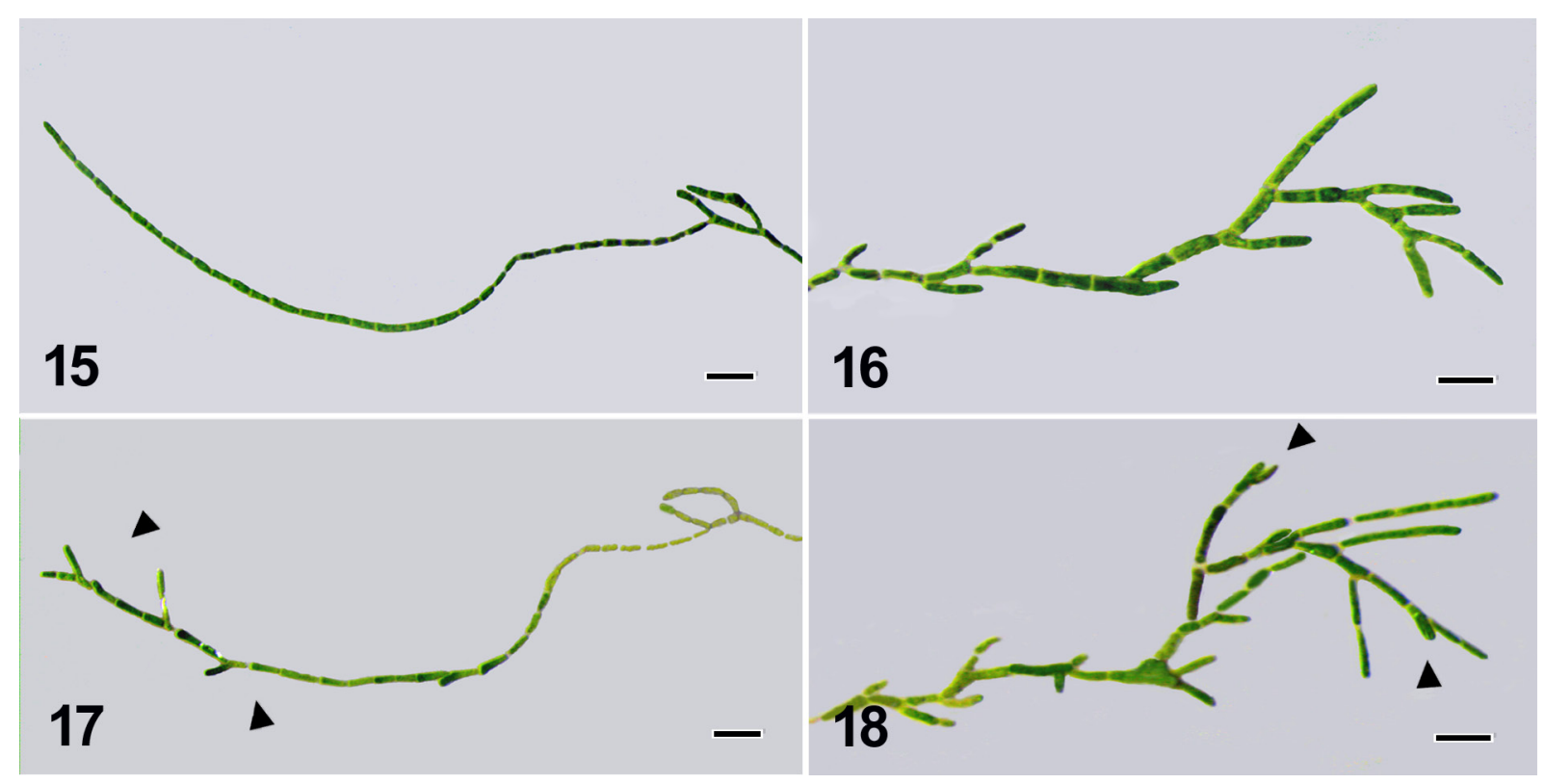

Figs $15-18$. Rhizoclonium ramosum in culture: $(15,16)$ gross thalli morphology of primary states in culture; $(17,18)$ new branches developped on solid medium after two weeks (arrows). Scale bar $100 \mu \mathrm{m}(15,16,17,18)$.

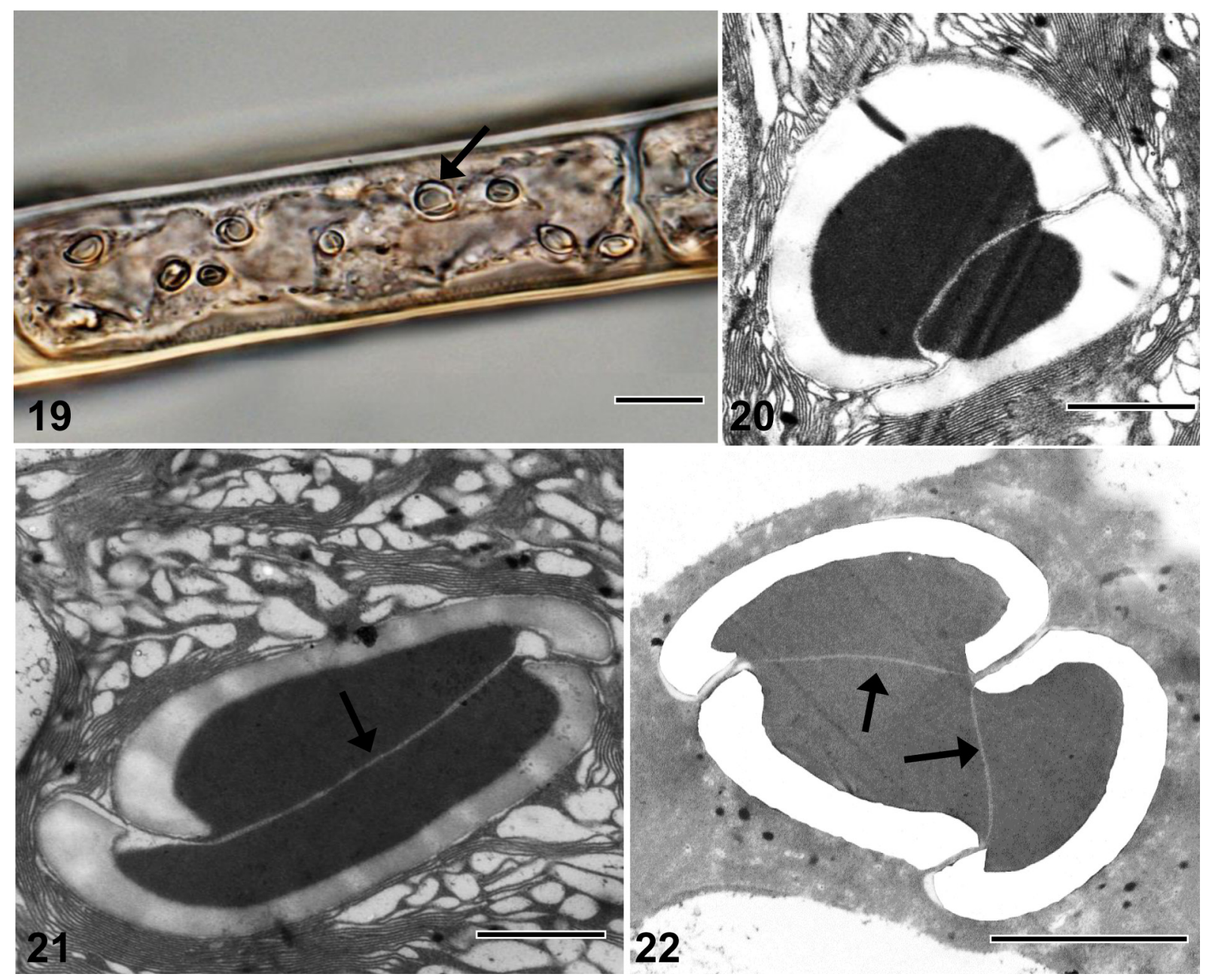

Figs 19-22. The LM (19) and TEM images (20, 21, 22) of the pyrenoid ultrastructure in Rhizoclonium ramosum: (19) Bilenticular pyrenoid observed by the light microscopy; $(20,21)$ The structure of bilenticular pyrenoid surrounded by two starch plates with a single thylakoid (arrow); (22) Zonate pyrenoid with two intrapyrenoidal thylakoids (arrows) and three starch plates. Scale bar $20 \mu \mathrm{m}(19), 1 \mu \mathrm{m}(20,21), 2 \mu \mathrm{m}(22)$. 


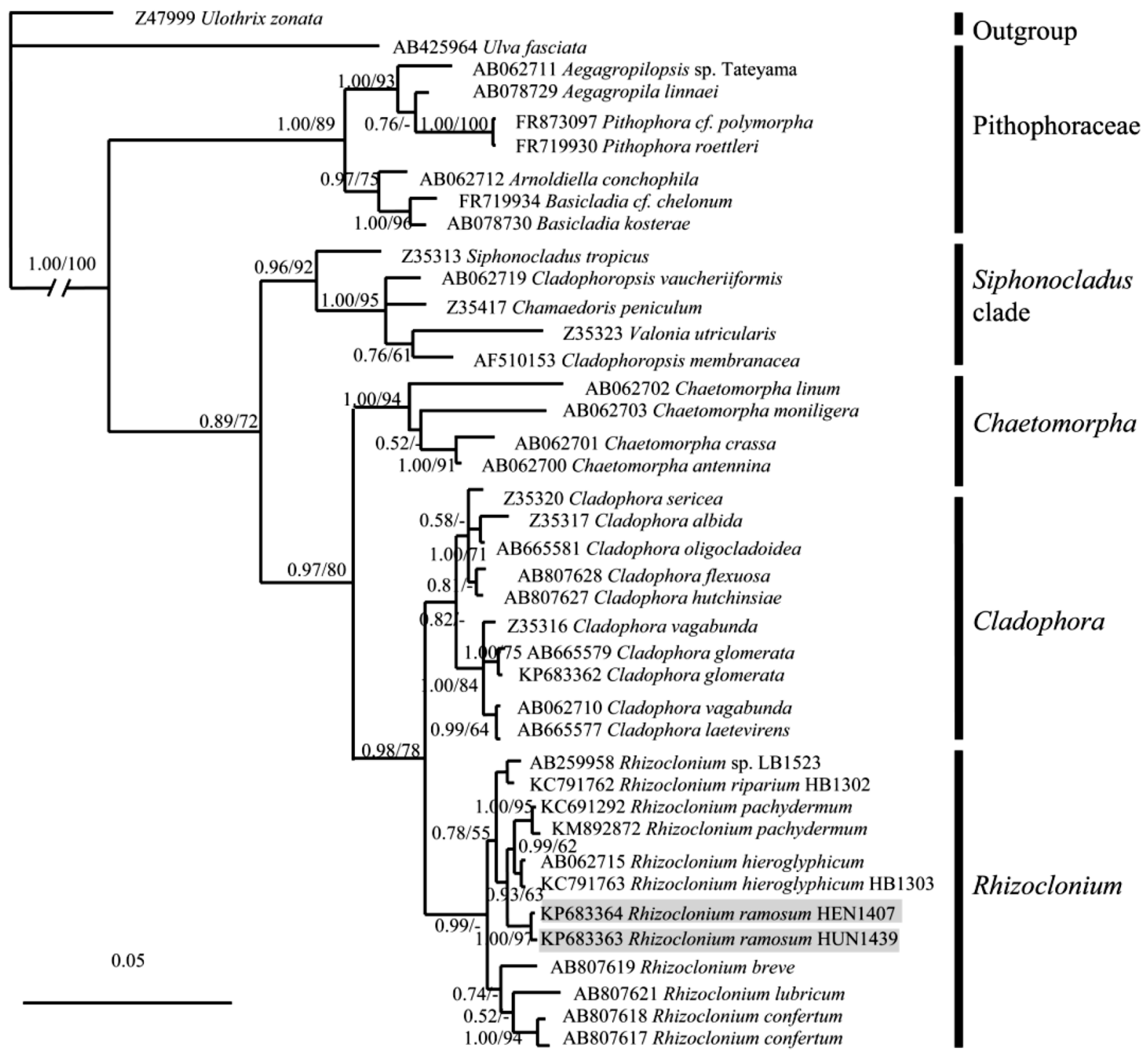

Fig. 23. Phylogenetic tree of the SSU rDNA sequences of Cladophorales. The posterior probabilities (PP) from Bayesian inference (BI) and ML bootstrap values are shown on the nodes. Values $>0.50$ are shown for BI and $>50$ for ML. The new species are shade in grey.

in Table S1. Phylogenetic trees showed the simple relationship between the five clades of Cladophorales - Pithophoraceae, Siphonocladus, Chaetomorpha, Cladophora, and Rhizoclonium (Figs 23, 24). In this SSU rDNA tree, seven subclades emerged in the genus Rhizoclonium. The base frequencies of SSU rDNA sequences were homogeneous across the 40 taxa and putative relatives. The overall average pairwise distance of SSU rDNA was 0.050 . In these bases, variable sites were 394 (24.6\%) and parsimoniously informative sites were 316 (19.7\%). The SSU genes of samples HEN1407 and HUN1439 were about 1602 bp long, and differed only by one site. They formed a highly supported group (1.00/97 for $\mathrm{BI} / \mathrm{ML})$. R. ramosum formed a clear sister group with other Rhizoclonium species (Fig. 23).

For LSU rDNA sequences, 32 sequences obtained from GenBank were used to construct a phylogenetic tree (Fig. 24). LSU sequences were about 537 $\mathrm{bp}$ and the overall average pairwise distance was 0.184 . Among these nucleotides, 296 sites (55.1\%) were variable and 242 sites $(45.1 \%)$ were parsimoniously informative. The LSU rDNA phylogenetic tree supported the SSU rDNA topology relationship further (Fig. 24). The SSU phylogenetic trees constructed by ML and BI methods showed similar topologies, and only the Bayesian trees are presented here.

\section{Discussion}

This filamentous green alga, isolated from the surface of rocks, has distinct morphological characteristics (Figs 3, 4, 13, 14), the formation of primary, secondary or more advanced branch, which distinguishes it from all the other Rhizoclonium species. The phylogenetic analysis was well supported (1.00/91 for SSU, 


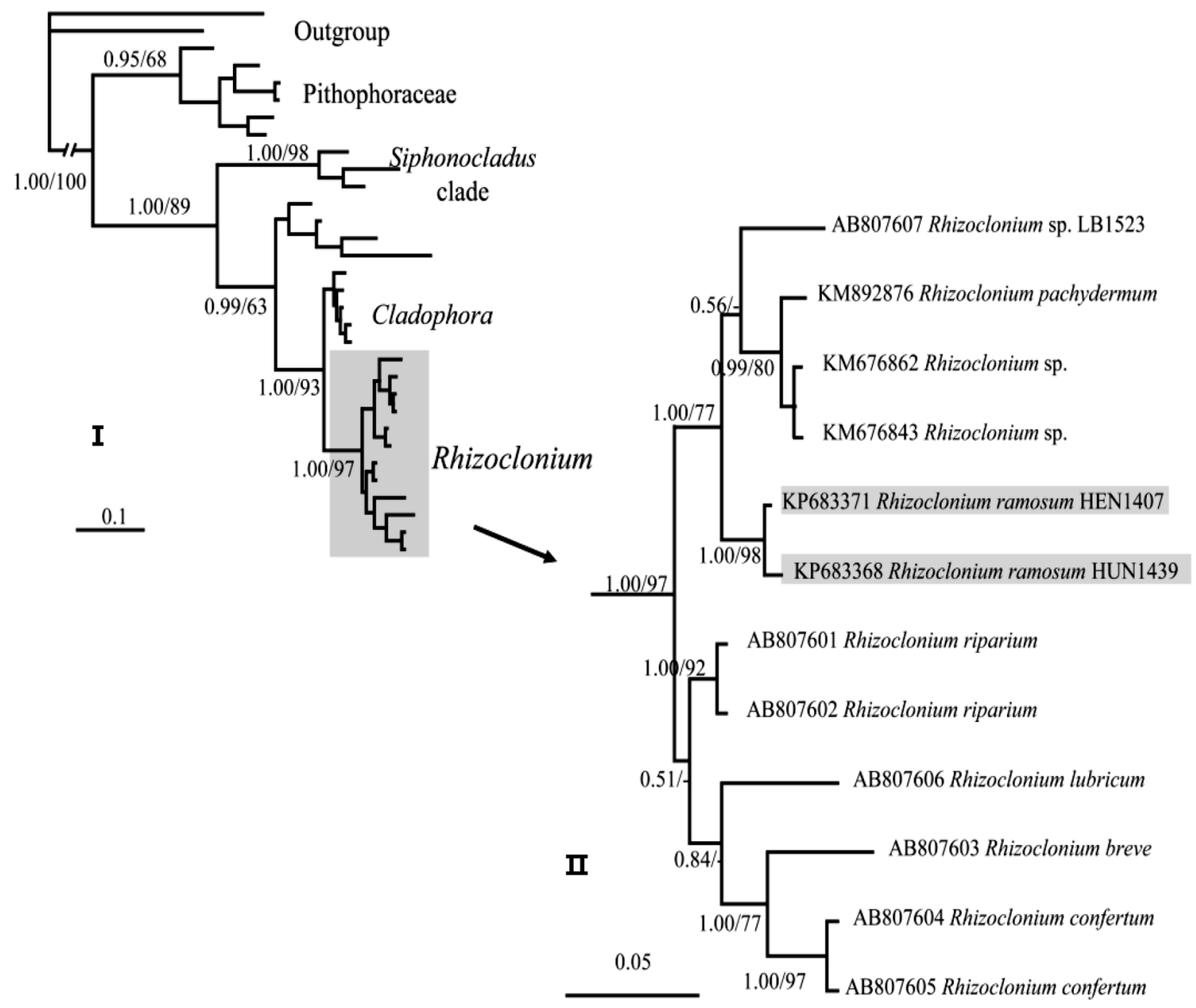

Fig. 24. ( I ) Phylogenetic tree of the LSU sequences of members of Cladophorales, with genus and family names shown. The posterior probabilities (PP) from Bayesian inference (BI) and ML bootstrap values are shown on the nodes. Values $>0.50$ are shown for BI and $>50$ for ML. ( II ) Close-up the "Rhizoclonium" clade highlighted in grey in ( I ), with the Rhizoclonium ramosum clade for better visualization.

1.00/95 for LSU) by other allied species (Figs 23, 24). Hence, we suggest this alga should be classified under Rhizoclonium as a new species: $R$. ramosum.

A morphological comparison between $R$. ramosum and allied Rhizoclonium and minute Cladophora species is summarized in Table 1 . Both $R$. ramosum and $R$. pachydermum have true branches, but their locations differ. The former branches from the basal region to the apical parts, while the latter branches only in the basal region. In addition, the nuclear number of $R$. ramosum is $4-17$, which is 3 to 4 times more than $R$. pachydermum (1-4). The discoid holdfast of $R$. pachydermum was not observed in our samples. The pyrenoid ultrastructure of $R$. ramosum is similar to that of $R$. breve: bilenticular, with the rare zonate type (Table 1); however, the species differ in L/D ratio, nuclear number, and molecular data (Figs 23, 24). Branches were also reported in $R$. fractiflexum and $R$. fontanum, but these were short and sparse (STOCKMAYER 1890; Prescott 1961; Gardavsky 1993). No secondary branches were found in these species. Some minute Cladophora species, such as C. globulina and
C. fracta, are similar in size to Rhizoclonium species (VAN Den Hoek 1963; Liu 1999). R. ramosum can be distinguished morphologically from these Cladophora species by a smaller L/D ratio.

Nevertheless, $R$. ramosum still shares common morphological features with other Rhizoclonium species: the cell diameter is $<60 \mu \mathrm{m}$, they have a smaller $\mathrm{L} / \mathrm{D}$ ratio $(<6)$, and they have few nuclei, in agreement with the results of ICHIHARA et al. (2013) and Zhao et al. (2014). Moreover, the simple rhizoids (Fig. 7), the lateral insertion of the rhizoidal branches (Figs 8,9), and the mode of growth by intercalary cell divisions are also important features of the genus Rhizoclonium. In the present study, the rhizoidal laterals usually contained 1-3 cells and the chloroplasts were absent or uneven, which is similar to the structure reported in $R$. riparium, $R$. fontanum, and $R$. hieroglyphicum (STARMACH 1972; FARIDI 1983; PARODI \& CÁCERES 1993). The presence or absence of rhizoidal laterals was used as a diagnostic character for the delineation of Rhizoclonium by Starmach (1972) and Blair (1983). Cells of these laterals are always short, sparse, and irregular. 
However, in $R$. ramosum and $R$. pachydermum, real branches are cylindrical and uniform, and the diameter is as wide as the main axes. Branch proliferation and complexity in $R$. ramosum are probably influenced by environmental conditions such as the running water, light, and substratum firmness. For instance, NIENHUIS (1975) reported that substratum firmness affected the growth of rhizoidal laterals. Besides, CHRISTENSEN (1991) explained the formation of basal branches of $R$. pachydermum by akinetes. So, we speculate the clustered thalli may be the result of many years' growth with the help of akinetes. The culture results of $R$. ramosum (Figs 17, 18) indicated that developing branches have stability, while rhizoids and rhizoidal laterals have plasticity. While this morphological characteristic "branches" can be used for distinguishing Rhizoclonium species, it is not necessarily an effective phylogenetic marker to differ the Rhizoclonium clade from other Cladophorales clades.

Much research has been carried out on morphology by several taxonomists (e.g. Nienhuis 1975; Blair 1983; Posada \& CRANDAll 1998) but stable, efficient features and DNA sequences are still lacking. This leads to much confusion and controversy regarding taxonomic classification. It is clear that more sampling and ultrastructural and molecular analyses are needed to further clarify the diversity and phylogeny of the genus Rhizoclonium.

ACKnowledgements

This work was financially supported by the National Natural Science Foundation of China (No. 31270252)

\section{REFERENCES}

BLAIR, S.M. (1983): Taxonomic treatment of the Chaetomorpha and Rhizoclonium species (Cladophorales; Chlorophyta) in New England. - Rhodora. 85: 197-209.

Chapman, V.J. (1956): The marine algae of New Zealand, part I, Myxophyceae and Chlorophyceae. - Bot. J. Linn. Soc. 55: 333-501.

Christensen, T. (1991): On some Cladophoraceae (Chlorophyta) with long unbranched filaments. - Archiv fur Protistenkunde 139: 9-19.

De Toni, G.B. (1889): Sylloge algarum omnium hucusque cognitarum. Vol. I. Chlorophyceae. - 1315 pp., typis seminarrii.

FARIDI, M.A.F. (1983): A monograph of the freshwater species of Rhizoclonium. - Biologia. 29: 211-223.

Gardavsky, A. (1993): Rhizoclonium fractiflexum sp. nova, a New Member of Cladophorales (Chlorophyta) Described from Freshwater Aquaria. - Archiv fur Protistenkunde 143: 125-136.

GurRY, M.D. \& GuirY, G.M. (2015): AlgaeBase. World-wide electronic publication, National University of Ireland, Galway. URL http://www.algaebase.org/.

Hall, T.A. (1999): BioEdit: A user-friendly biological sequence alignment editor and analysis program for Windows 95/98/NT. - Nucleic Acids Symp. Ser. 41:
95-98.

Hanyuda, T.; Wakana, I.; Arai, S.; Miyaji, K.; Watano, Y. \& Ueda, K. (2002): Phylogenetic relationships within Cladophorales (Ulvophyceae, Chlorophyta) inferred from 18S rRNA gene sequences, with special reference to Aegagropila linnaei. - J. Phycol. 38: 564-571.

Hassouna, N.; Michot, B. \& Bachellerie J.P. (1984): The complete nucleotide sequence of mouse $28 \mathrm{~S}$ rRNA gene. Implications for the process of size increase of the large subunit rRNA in higher eukaryotes. Nucleic Acids Res. 12: 3563-3583.

Huelsenbeck, J.P. \& Crandall, K.A. (1997): Phylogeny estimation and hypothesis testing using maximum likelihood. - Annu. Rev. Ecol. Evol. Syst. 28: 437-466.

ICHIHARA, K.; ShImAdA, S. \& MiYAJ, K. (2013): Systematics of Rhizoclonium-like algae (Cladophorales, Chlorophyta) from Japanese brackish waters, based on molecular phylogenetic and morphological analyses. - Phycologia 52: 398-410.

JAO, C.C. (1947): Studies on the freshwater algae of China XVII: Ulotrichales, Siphonocladiales, and Siphonales from Kwangsi. - Bot. Bull. Acad. Sinica 1: 257-269.

John, D.M.; Whitton, B.A. \& Brook, A.J. (2002): The freshwater algal flora of the British Isles: An identification guide to freshwater and terrestrial algae. $-714 \mathrm{pp}$., Cambridge University Press, UK.

KJellmann, F.R. (1877): Ueber die Algenvegetation des Murmanschen Meeres an der Westkuste von Nowaja Semlja und Wajgatsch. - Nova Acta Reg. Soc. Sci. Ups., Vol. e.o. 12: 1-85.

KützING, F.T. (1843): Phycologia Generalis. - 458 pp., FA Brockhaus, Leipzig.

KÜTZING, F.T. (1849): Species Algarum. - 922 pp., FA Brockhaus, Leipzig.

Leliaert, F.; Rousseau, F.; De Reviers, B. \& Coppejans E. (2003): Phylogeny of the Cladophorophyceae (Chlorophyta) inferred from partial LSU rRNA gene sequences: is there cognition of a separate order Siphonocladales justified? - Eur. J. Phycol. 38: 233-246.

Leliaert T. F. \& Boedeker, C. (2007): Cladophorales. - In: Brodie, J.; Maggs, C.A. \& John, D.M. (eds): Green seaweeds of Britain and Ireland. - pp. 131-183, Natural History Museum Publications, London, UK.

LiU, G.X. (1999): Study on the systematics of freshwater Cladophoraceae from China. - 75 pp., Institute of Hydrobiology, Chinese Academy Sciences.

Matsuyama, K.; Matsuoka, T.; MiyaJi, K.; TanaKa, J. \& ARUGA, Y. (1998): Ultrastructure of the pyrenoid of Cladophoraceae (Chlorophyta). - J. Jpn. Bot. 73: 279-286.

MiYaJ, K. (1999): A new type of pyrenoid in the genus Rhizoclonium (Cladophorales, Chlorophyta). - Phycologia 38: 267-276.

Nienhuis, P.H. (1975): Biosystematics and ecology of Rhizoclonium riparium (Roth) Harvey (Chlorophyceae: Cladophorales) in the estuarine area of the rivers Rhine, Meuse, and Scheldt. - 240pp., Rotterdam.

Nitschke, U.; Boedeker, C.; Karsten, U.; Hepperle, D. \& EGGERT, A. (2010): Does the lack of mannitol accumulation in an isolate of Rhodella maculata (Rhodellophyceae, Rhodophyta) from the brackish Baltic Sea indicate a stressed population at the distribution limit? - Eur. J. Phycol. 45: 436-49. 
PAROdi, E.R. \& CÁceres, E.J. (1993): Life history of freshwater populations of Rhizoclonium hieroglyphicum (Cladophorales, Chlorophyta). - Eur. J. Phycol. 28: 69-74.

Posada, D. \& Crandall, K.A. (1998): Modeltest: testing the model of DNA substitution. - Bioinformatics 14: $817-818$.

Prescott, G.W. (1961): Algae of the western Great Lakes area with an illustrated key to the genera of desmids and freshwater diatoms. - 142 pp., Wm. C. Brown, Dubuque, Iowa.

Ronquist, F. \& HuelsenBeCK, J.P. (2003): MRBAYES 3: Bayesian phylogenetic inference under mixed models. - Bioinformatics 19: 1572-1574.

Setchell, W.A. \& Gardner, N.L. (1920): The marine alage of the Pacific coast of North America. Part. 2, Chlorophyceae. - Univ. Calif. Publicat. Bot. 2: 139-374.

Starmach, K. (1972): Flora Slodkowodna Polski. - 750 pp., Polska Akademia Nauk Instytut Botaniki, Krakow.

Stockmayer, S. (1890): Über die Algengattung Rhizoclonium. - Verh. zool.-bot. Ges. Wien 40: 571-586.

Swofford, D.L. (1998): PAUP*: Phylogenetic analysis using parsimony (*and other methods), version 4.0 Beta. Sunderland, Massachusetts: Sinauer.

Thompson, R.H. \& Wujek, D.E. (1997): Trentepohliales: Cephaleuros, Phycopeltis, and Stomatochroon: morphology, taxonomy and ecology. - 149 pp., Science Publishers, New Hampshire.

VAN Den Hoek, C. (1963): Revision of the European species of Cladophora. - 294pp., Brill, Leiden.

Van Den Hoek, C. \& Chinara M. (2000): A taxonomic revision of the marine species of Cladophora (Chlorophyta) along the coasts of Japan and the Russian
Far-east. - 242pp., National Science Museum, Tokyo.

Verma, B.N. (1986): Cytotaxonomical studies in the Genus Rhizoclonium Kutz. - Cytologia 51: 177-183.

West, W. \& West G.S. (1897): Welwitsch's African freshwater algae. - J. Bot. 35: 33-42.

Zhао, Z.J.; Zhu, H.; Hu, Z.Y. \& Liu, G.X. (2014): Occurrence of true branches in Rhizoclonium (Cladophorales, Ulvophyceae) and the reinstatement of Rhizoclonium pachydermum Kjellman. - Phytotaxa 166: 273-284.

Supplementary material

the following supplementary material is available for this article:

Table S1. Specimens used in the phylogenetic analysis with their collection information and GenBank accession numbers.

This material is available as part of the online article (http://fottea.czechphycology.cz/contents)

(C) Czech Phycological Society (2016)

Received June 8, 2015

Accepted October 14, 2015 